\title{
MERANCANG KOMUNITAS ANAK MUDA BERBASIS ARSITEKTUR EKOLOGI
}

\author{
Estefany Betzy Gultom ${ }^{1)}$, Mieke Choandi ${ }^{2)}$ \\ 1)Program Studi S1 Arsitektur, Fakultas Teknik, Universitas Tarumanagara,estefany.315170207@stu.untar.ac.id \\ 2)Program Studi S1 Arsitektur, Fakultas Teknik, Universitas Tarumanagara, miekec@ft.untar.ac.id
}

Masuk: 04-07-2021, revisi: 12-08-2021, diterima untuk diterbitkan: 23-10-2021

\begin{abstract}
Abstrak
Pada masa pandemi kegiatan belajar-mengajar tidak berlangsung secara maksimal. Baik dalam kegiatan sosial atau pembelajaran formal, semuanya harus dibatasi mengikuti peraturan pemerintah. Dan di era globalisasi seperti sekarang ini dimana manusia memanfaatkan sumber daya alam dengan tidak teratur dan melakukan banyak pembangunan yang mengeksploitasi ekosistem. Pembangunan seharusnya lebih memperhatikan upaya untuk menjaga ekosistem alam karena sumber daya alam tidak hanya untuk generasi sekarang namun untuk kebutuhan generasi muda di masa depan. Kota Bogor sendiri memiliki banyak potensi baik di bidang sosial maupun ekologinya. Iklim kota Bogor sangat bagus dimana kotanya sendiri terkenal dalam hal pertanian dan perkebunan. Penghuni kota Bogor mayoritas adalah penduduk di usia produktif. Fasilitas anak muda di kota Bogor sendiri sudah tersedia namun program yang ditawarkan lebih mengarah ke kegiatan non akademik. Sehingga bangunan dirancang untuk mewadahi kebutuhan anak muda mulai dari kebutuhan non-akademik sampai ke kebutuhan pendidikan non-formal. Dengan program-program yang ditawarkan, yang bertujuan untuk meningkatkan kualitas sosial dan ekonomi anak muda di Kota Bogor. Penerapan metode Arsitektur Ekologi dalam merancang fasilitas untuk anak muda di Kota Bogor diaplikasikan pada program dan sistem perawatan dalam bangunan, yang mengacu terhadap 6 Beyond Ecology Principal. Pengunaan tema simbiosis yang diaplikasikan pada program bangunan dan juga sistem perawatan bangunannya, yang bertujuan untuk menghemat energi.
\end{abstract}

Kata Kunci: Arsitektur Ekologi; Ekologi; Komunitas Anak Muda.

\begin{abstract}
During the pandemic, student activities do not take place optimally. Whether in the social activities or formal learning, everything must be limited following government regulations. And these days, where humans use natural resources irregularly and do city development that exploits the ecosystem. When we are doing a development. We should pay more attention and efforts to maintain natural ecosystems, because natural resources are not only for the current generation but for the needs of younger generation in the future. The city of Bogor itself has a lot of potential both in the social and ecological fields. Bogor weather climate is very good where the city itself is famous in terms of agriculture and plantations. The majority of residents in the city of Bogor are on a productive age. Facilities for adolesence itself are already available, but the programs that offered are more directed to non-academic activities. Therefore this building is designed to accommodate the needs of young people ranging from non-academic needs to the needs of non-formal education. With the programs that offered, which aim to improve the social and economic quality of young people in the city of Bogor. Ecological Architecture method are used in this building. It is applied to the program and maintenance building systems, which refers to the 6 Beyond Ecology Principals. The use of a symbiotic theme is applied to the building program and also the building maintenance system, which aims to save energy.
\end{abstract}

Key Words: Ecology; Ecology Architecture; Youth Centre 


\section{PENDAHULUAN}

\section{Latar Belakang}

Dunia kita telah berubah, setelah datangnya pandemi Covid-19. Pandemi ini berdampak ke semua sektor kehidupan masyarakat, mulai dari ekonomi, kebiasaan dan kehidupan sosial masyarakat, mulai dari ekonomi, kebiasaan dan kehidupan sosial masyarakat. Masyarakat dipaksa untuk mengubah pola perilaku sosial mereka, dari yang biasanya bekerja ditempat kerja, belajar disekolah, semuanya sekarang harus dilakukan dirumah. Terlebih lagi bagi para remaja yang seharusnya belajar dirumah tetapi dipaksa untuk melakukan kegiatan belajar mengajar dari rumah. Tidak semua orang tua dapat membimbing anaknya belajar di rumah, kurangnya pengawasan dari orang dewasa menyebabkan meningkatnya tingkat remaja putus sekolah selama masa covid ini. Menurut survei Badan Pusat Statistik (BPS), penyebab putus sekolah antara lain; latar belakang pendidikan orang tua, lemahnya ekonomi keluarga, kurangnya minat anak untuk bersekolah, kondisi lingkungan tempat tinggal anak hingga pandangan masyarakat terhadap pendidikan. Dan angka putus sekolah yang paling tinggi terjadi pada siswa Sekolah Menengah Kejuruan (SMK). Dalam kurun waktu tiga tahun terakhir, pertumbuhan angka putus sekolah di kalangan SMK mencapai 0,45 persen. (Valenta, 2019).

\section{Rumusan Permasalahan}

Menurut Talcott Parson (1951), peran sosial yang tidak berfungsi dengan baik di masyarakat akan menimbulkan penyimpangan pada individu terkait. (Parsons, 1951) Fenomena yang ditemukan adalah meningkatnya angka anak jalanan di kota Bogor. Pandemi yang sedang terjadi sekarang ini mempengaruhi banyak sekali aspek kehidupan. Faktor ekonomi menjadi salah satu alasan mengapa anak muda banyak yang berhenti sekolah. Mereka yang tidak mampu melanjutkan pendidikan formal cenderung melakukan kegiatan yang bersifat negatif. Karena kurangnya pendidikan dan kemampuan yang dapat digunakan untuk bekerja. Kurangnya aktivitas sosial bagi remaja juga berdampak ke kesehatan mental individu.

\section{Tujuan}

Maka Gedung Komunitas akan menjadi suatu solusi yang tepat untuk masalah ini. Dimana anak remaja akan memiliki kegiatan sosial yang positif dan nantinya dapat mereka gunakan sebagai kemampuan dasar dalam berkarir atau berkarya. Gedung Komunitas menawarkan programprogram yang akan meningkatkan kualitas akademik dan non-akademik remaja. Memberikan program yang mengedukasi dan memanfaatkan teknologi terbaru sebagai upaya untuk meningkatkan kualitas masyarakat. Selain sebagai fasilitas pembelajaran dan pelatihan, program juga menyediakan fasilitas yang mendukung kebutuhan anak muda, misalnya seperti ruang untuk berolahraga, ruang untuk menyalurkan hobi seni, ruang untuk melakukan kegiatan kelompok dan sebagainya.

Generasi muda memiliki populasi paling banyak di negara ini, maka pentingnya memberikan arahan dan bimbingan bagi generasi muda sudah harus menjadi pertimbangan. Karena generasi muda saat inilah yang nantinya akan memegang peran untuk membangun lingkungan alam dan sosial.

\section{KAJIAN LITERATUR}

\section{Kajian Gedung Komunitas}

Masalah sosial yang dialami remaja pada saat ini sudah seharusnya menjadi perhatian. Pandemi yang membatasi kegiatan sosial masyarakat berpengaruh juga ke aspek kehidupan lainnya mulai dari ekonomi hingga Kesehatan mental. Masa remaja merupakan masa yang memiliki peran penting dalam rentang kehidupan manusia. Remaja adalah individu yang sedang dalam tahap "transisi", melepas masa anak-anaknya ke masa dewasa. Mereka mengalami banyak perubahan, baik secara fisik, emosional, intelektual, dan sosial. (Santrock, 2011) Remaja yang seharusnya mendapatkan pendidikan dan pengawasan lebih tidak dapat terpenuhi kebutuhannya. Faktor 
ekonomi juga menjadi salah satu alasan anak remaja tidak mendapat pendidikan yang semestinya. Banyak anak muda yang terpaksa putus sekolah dan melakukan kegiatan yang merugikan, karena kurangnya kemampuan dan pengetahuan untuk bekerja. Objek rancangan ini adalah Gedung Komunitas Anak Muda dengan pendekatan tema Arsitektur Ekologi. Bangunan ini berfungsi sebagai wadah komunitas anak muda di Bogor untuk beraktivitas dengan pendekatan arsitektur ekologi yang menggunakan konsep simbiosis pada bangunannya.

\section{Kajian Arsitektur Ekologis}

The Philosophy of Symbiosis (1994) karya Kisho Kurukawa, menjelaskan bagaimana fenomena globalisasi semakin cepat terjadi dan akan berubah dari zaman mesin ke zaman kehidupan yang wajar berdasarkan pemikiran holistic. (Kurokawa, 1994)Arsitektur ekologis bergantung pada konsep ekosistem, yaitu komponen lingkungan hidup harus dilihat secara terpadu dengan lingkungannya, berkaitan dan saling bergantung antara satu dengan yang lainnya dalam suatu sistem. Pendekatan ekosistem atau pendekatan holistic biasanya digunakan dalam menerapkan konsep ini. Dalam ekosistem sendiri terjadi suatu siklus, yaitu suatu kondisi peralihan dari satu fenomena ke fenomena lainnya secara berulang-ulang seakan-akan berbentuk suatu lingkaran siklus. Ekosistem sendiri terdiri dari makhluk hidup (biotik) dan lingkungan (abiotic). Kedua unsur tersebut masing-masing memiliki pengaruh antara satu sama lain untuk memelihara kehidupan sehingga terjadi suatu keseimbangan di bumi.

Arsitektur Ekologis akan tercipta apabila dalam proses perancangannya menggunakan pendekatan desain yang ekologis atau memikirkan alam sebagai basis perancangan. Proses pendekatan arsitektur yang menggabungkan alam lokal dengan teknologi, menggunakan alam sebagai basis design dan strategi konservasi sumber daya alam sebagai upaya untuk perbaikan lingkungan. Hal ini dapat diaplikasikan ke dalam bangunan dalam hal pengudaraan, pengaturan sistem air dan lainnya. Menurut Heinz Frick dalam buku "Arsitektur Ekologi" (Frick \& Mulyani, Arsitektur Ekologis, 1998), arsitektur ekologis memiliki sifat-sifat khusus yaitu: 1. Holistis; berhubungan dengan sistem keseluruhan, sebagai suatu kesatuan yang lebih penting daripada sekedar kumpulan bagian. 2. Memanfaatkan pengalaman manusia (tradisi dalam pembangunan), dan pengalaman lingkungan alam terhadap manusia. 3. Pembangunan sebagai proses dan bukan sebagai kenyataan tertentu yang statis. 4. Adanya kerja sama antara manusia dengan alam sekitarnya demi kelestarian alam

\section{Beyond Ecology}

Ekologi sendiri terdiri dari berbagai macam sistem komunitas yang berkesinambungan antara satu sama lain dalam sebuah ekosistem. Di era globalisasi seperti sekarang ini dimana manusia memanfaatkan sumber daya alam dengan sembarangan. Banyak pembangunan yang mengeksploitasi ekosistem. Maka dari itu pentingnya merencanakan pembangunan demi menjaga ekosistem alam harus dijadikan prioritas. Karena sumber daya alam tidak hanya untuk generasi sekarang namun juga untuk kebutuhan di masa depan.

Menurut Agustinus Sutanto(februari,2021), tentang Beyond ecology memiliki 6 hal penting yang perlu diperhatikan : 1. Energy and Emission; Kemampuan untuk menerapkan zero emisi karbon dalam operasi bangunan dan menggunakan material yang meminimalisir efek karbon. 2 . Adaptation; Kemampuan untuk melakukan perancangan berdasarkan riset data besar. 3 . Resilience; Kemampuan untuk membangun kelanjutan dalam bangunan. 4. Sustainable Digital; Kemampuan melihat data lingkungan untuk menentukan strategi design dalam membangun kualitas rancangan. 5. New Technology; Kemampuan memanfaatkan atau menciptakan technology baru untuk meningkatkan kualitas rancangan. 6. Context; Kemampuan melihat hubungan antar rancangan dengan lingkungan. 


\section{METODE PENELITIAN}

Metode pengumpulan data sebagai prosedur sistematis untuk memperkuat ide dasar dari perancangan proyek. Data yang dikumpulkan terdiri dari dua macam yaitu data primer dan sekunder. Data primer diperoleh dari penelitian secara langsung dari data dan informasi yang sudah ada, sedangkan data sekunder berasal dari data yang sudah diolah.

Metode perancangan merupakan cara berfikir dengan menyesuaikan rumusan masalah dan tujuan perancangan hingga menghasilkan suatu hasil rancangan. Metode rancangan yang dipilih untuk proyek ini adalah arsitektur ekologis. Metode arsitektur ekologis sebagai solusi dalam menciptakan ruang komunitas yang dapat mendukung produktivitas remaja.

\section{PEMBAHASAN DAN HASIL}

Berdasarkan proyek yang akan dijalankan, ada beberapa faktor yang mempengaruhi pemilihan tapak. Salah satunya adalah banyaknya komunitas yang menjadi sasaran. Sesuai dengan tujuan proyek yang ingin meningkatkan kegiatan komunitas di suatu daerah tertentu agar dapat sadar akan pentingnya kesadaran akan lingkungan. Untuk mencapai tujuan tersebut, terdapat beberapa kriteria dalam pemilihan tapak:

a) Lokasi berada di wilayah yang banyak komunitas sesuai dengan tapak.

b) Lokasi berada di wilayah yang mudah dijangkau dengan kendaraan pribadi maupun kendaraan umum

c) Lokasi dekat dengan fasilitas kota yang mendukung seperti terminal kendaraan umum, retail dan lain-lain

Berdasarkan data yang tersedia mengenai remaja, diketahui bahwa kota Bogor memiliki populasi anak remaja yang paling banyak di provinsi Jawa Barat.

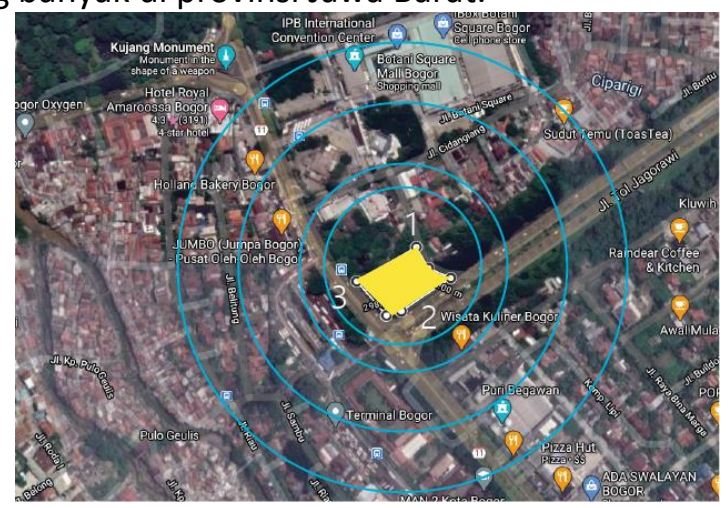

Gambar 1. Peta Kota Bogor

Sumber: Google Map
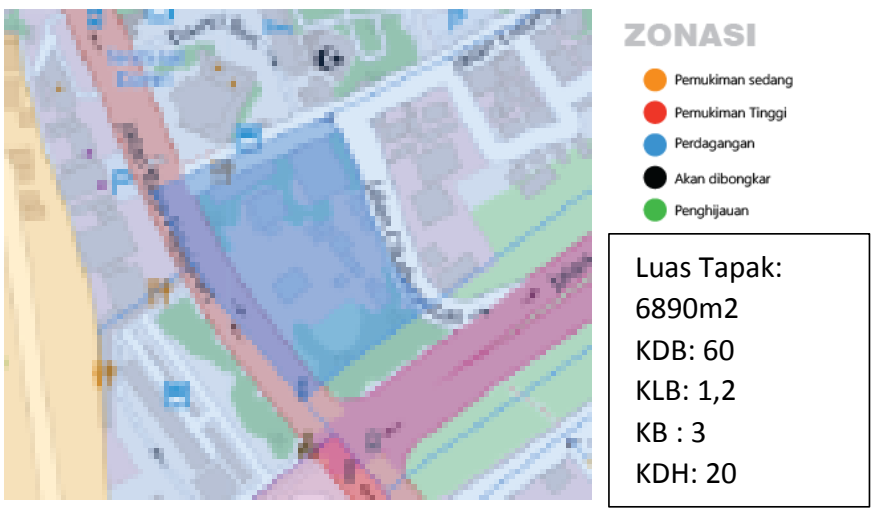

Gambar 2. Peta Zonasi Kota Bogor

Sumber: http://tataruang.kotabogor.go.id 
Lokasi tapak berada di Jl. Raya Bogor- Sukabumi, Kecamatan Bogor Tengah,Kota Bogor. Tapak berada di pusat kota dekat dengan pintu tol Kota Bogor. Tapak berbatasan langsung dengan area zonasi perdagangan \& jasa. Lokasi tapak sendiri dekat sekali dengan kampus IPB (Institut Pertanian Bogor) dan juga Kebun Raya Bogor. Batasan lokasi tapak: Sebelah Utara : Ruko Petokoan; Sebelah Selatan: Jl. Raya Bogor - Sukabumi; Sebelah Barat : Tanah kosong; Sebelah Timur: Jl. Tol Jagorawi.

\section{Program}

Sejak tahun 1960-an di Amerika dan Eropa sudah marak Gerakan pendekatan perancanaan dan perancangan yang mengutamakan unsur moral dan politik, berkeadilan sosial. Gerakan ini kemudian menghasilkan beberapa paradigma dalam perencanaan dan perancangan partisipatif seperti Community Architecture (Day, 2003). Maka program yang tawarkan berorientasi kepada kegiatan komunitas yang dapat mendukun keproduktivitasan masyarakat. Program yang disediakan; aktivitas olahraga berupa lapangan basket lapangan bulutangkis, aktivitas workshop berupa workshop lukis, workshop tari dan kegiatan-kegiatan yang akan disediakan oleh pengelola setiap harinya, aktivitas penunjang berupa co-learning space, open market dan juga foodcourt yang memiliki sifat fungsi publik. Hasil rancangan berbasis sosial dan lingkungan lokal dari tapak. Yang bertujuan untuk meningkatkan value lokalitas wilayah dan juga membangun komunitas sosial yang produktif.

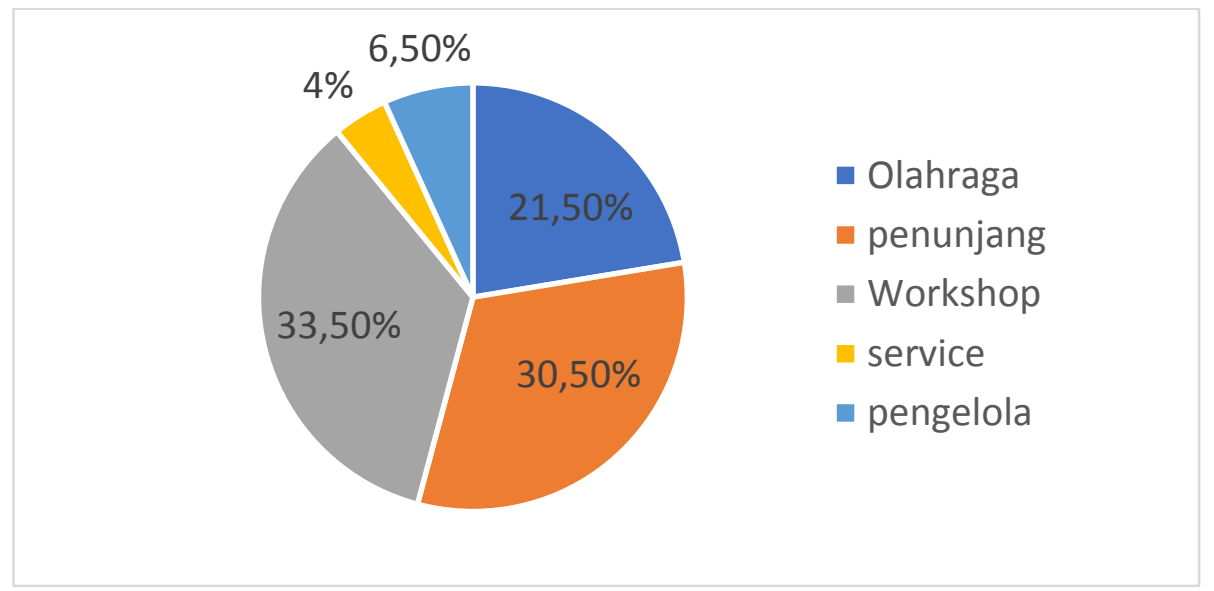

Gambar 3. Grafik Persentase Kelompok Fungsi

Sumber: Data Penulis, 2021

Program bangunan dibagi menjadi 5 kategori sesuai fungsinya. Program Youth Centre yang berupa sarana dan fasilitas bagi remaja untuk mengapresiasikan hobinya. Program ruang berupa lapangan yang akan mendukung aktifitas olahraga, kelas workshop yang akan memfasilitasi kegiatan komunitas remaja sekitar dan juga Co-Learning Space yang dapat dimanfaatkan oleh remaja. Menyediakan sarana dan pra-sarana untuk masyrakat agar dapat mempelajari tentang urban vertical farming. Kelas akan diselenggarakan dengan sistem per-batch. Materi yang diajarkan akan mulai dari penanaman bibit, pembuatan media tanam sampai ke penyemaian. Program ini dibangun dengan tujuan dapat meningkatkan kualitas ekonomi lokalitas wilayah. Hasil tanam dari vertical garden akan di distribusikan ke UMKM sekitar atau juga dijual di open market dan diolah menjadi makanan jadi di foodcourt. Program pendukung berupa foodcourt dan open market. Foodcourt diisi oleh masyarakat seita yang mengolah bahan mentah dari hasil vertical garden menjadi bahan makanan yang dijual di foodcourt. Dan juga open market yang menjual hasil bahan mentah dari vertical garden yang juga didistribusikan ke UMKM sekitar. Dengan jumlah area terbanyak digunakan untuk program utama yaitu workshop. Ruang workshop program diatur pengelola dan disewakan, sehingga besaran ruang kelasnya 
disesuaikan dengan jumlah kapasitas program workshop yang di tawarkan. Ruang tari dan workshop lukis bersifat sewa ditujukan untuk komunitas lokal yang sudah ada. Besaran ruang untuk kelas tari dan workshop lukis sudah disesuaikan dengan Co-learning space bersifat sewa perjam/harian, ditujukan untuk memfasilitasi mahasiswa dalam kegiatan belajar atau kerja kelompok. Ruang seminar juga bersifat sewa per minimal 3 jam. Workshop urban vertical farming menyediakan fasilitas untuk memperkenalkan dan mengajar sistem menanam baru yang bertujuan untuk meningkatkan produktivitas dan kualitas ekonomi masyarakat lokal. Dengan sistem kurikulum per batch dengan kurang lebih 4 kali pertemuan. Materi yang diajarkan berupa pembuatan media tanam, pembuatan pupuk dan pestisida organic, menyemai \& menanam sayuran, pengetahuan dasar tentang vertical farming.

\section{Konsep Dasar}

Dengan memanfaatkan tema arsitektur simbiosis, dengan tujuan agar dapat mencapai tujuan dari proyek yaitu menyelesaikan masalah sosial dan lingkungan. Tema arsitektur simbiosis di terapkan pada program bangunan dan juga sistem teknologi di bangunan. Tujuan dari konsep ini adalah untuk mempererat hubungan antara makhluk hidup (manusia) dengan alamnya. Dalam upaya untuk mewujudkan pelestarian sumber daya alam dalam banguan, digunakan sistem konsep simbiosis arsitektur. Yang memerlukan sistem operasional khusus dalam penggunaan energi di bangunan.

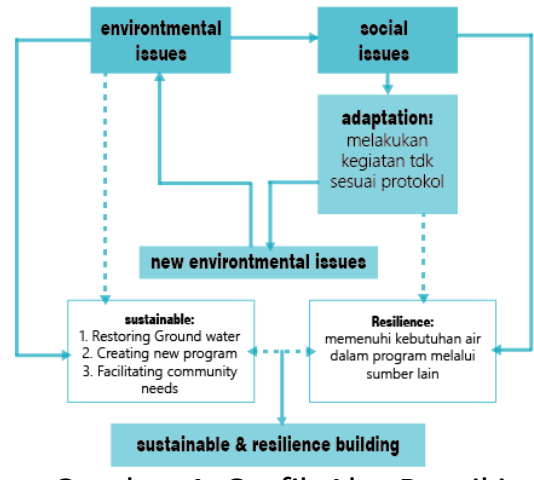

Gambar 4. Grafik Alur Berpikir Sumber: Data Penulis, 2021

Tema arsitektur ekologi digunakan dalam upaya menyelesaikan masalah Beyond Ecology. Arsitektur ekologi yang bersifat sustainable dan resilience dapat menjadi solusi terhadap masalah yang ada. Arsitektur ekologi juga sesuai dengan prinsip Beyond Ecology pada arsitektur tidak hanya membicarakan green building dan sustainability, tetapi juga dapat beradaptas, resilience, energi dan emisi konstruksi, serta mengikuti perkembangan zaman memadukan teknologi dalam pembangunan.

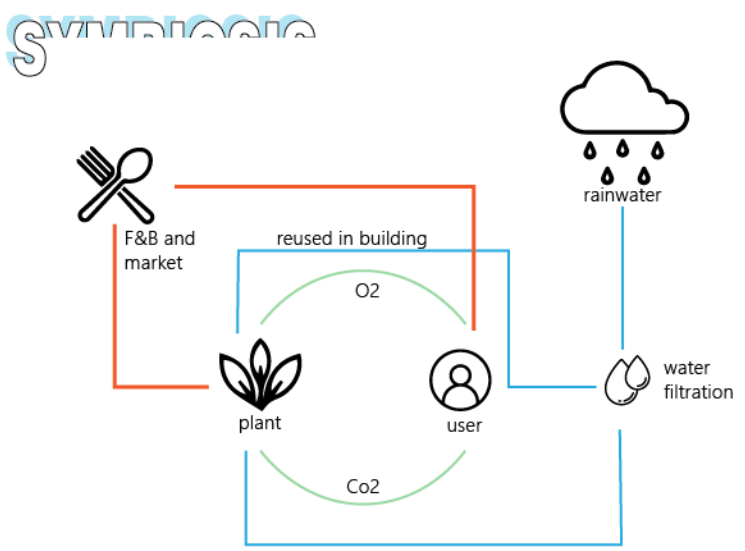

Gambar 5. Grafik Konsep Simbiosis dalam Bangunan Sumber: Data Penulis, 2021 
Simbiosis dalam bangunan ini sendiri diaplikasikan pada program, dan sistem sirkulasi air pada bangunan. Program vertical garden menghasilkan bahan mentah yang nantinya dapat diolah menjadi makanan siap saji yang dijual di foodcourt. Dan juga sistem mengumpulkan air hujan yang disaring melalui proses filtrasi yang kemudian digunakan di seluruh bangunan. Kesinambungan antara tanaman dan manusia juga memiliki hubungan simbiosis yang bagus dimana manusia menghasilkan $\mathrm{CO} 2$ yang dibutuhkan oleh tanaman dan juga sebaliknya.

Rancangan dibuat dengan mengikuti acuan dari 6 Beyond Ecology Principal sebagai upaya untuk mewujudkan bangunan yang sesuai dengan prinsip Beyond Ecology.

Tabel. 1. Beyond Ecology

\begin{tabular}{ll}
\hline $\begin{array}{l}6 \text { Beyond } \\
\text { Ecology } \\
\text { Principal }\end{array}$ & Keterangan \\
\hline $\begin{array}{l}\text { Energy and } \\
\text { Emision }\end{array}$ & $\begin{array}{l}\text { (Kemampuan untuk } \\
\text { menerapkan zero emisi } \\
\text { karbon dalam operasi } \\
\text { bangunan dan } \\
\text { menggunakan material yang } \\
\text { meminimalisir efek karbon.) }\end{array}$
\end{tabular}

Gambar 6. Perspektif Bangunan

Bangunan mayoritas bersifat semi masif agar dapat memaksimalkan cahaya dan pengudaraan alami

\begin{tabular}{lll}
\hline Adaptation & $\begin{array}{l}\text { Kemampuan untuk } \\
\text { melakukan perancangan } \\
\text { berdasarkan riset data } \\
\text { besar. }\end{array}$ & $\begin{array}{l}\text { Program disesuaikan dengan kegiatan komunitas yang } \\
\text { sudah banyak terjadi di Kota Bogor. }\end{array}$ \\
\hline Resilience & $\begin{array}{l}\text { Kemampuan untuk } \\
\text { membangun kelanjutan }\end{array}$ & $\begin{array}{l}\text { Ruangan semi masif dengan pengudaraan alami untuk } \\
\text { antisipasi penyebaran virus. }\end{array}$
\end{tabular}
dalam bangunan.

\begin{tabular}{ll}
\hline Sustainable & Kemampuan melihat data \\
Digital & lingkungan untuk \\
& menentukan strategi design \\
& dalam membangun kualitas \\
& rancangan
\end{tabular}

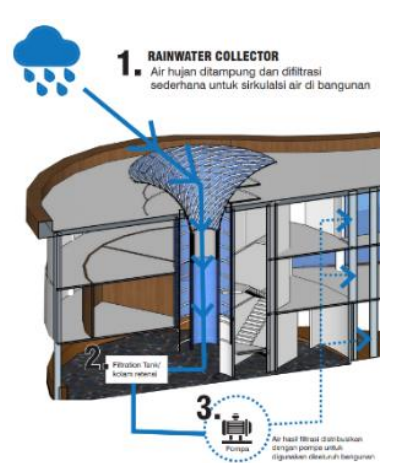

Menggunakan sistem menampung air hujan atas dasar data iklim di tapak

Gambar 7. Sistem Rainwatercollector

\begin{tabular}{lll}
\hline New & $\begin{array}{l}\text { Kemampuan memanfaatkan } \\
\text { Technology } \\
\text { atau menciptakan } \\
\text { technology baru untuk } \\
\text { meningkatkan kualitas } \\
\text { rancangan. }\end{array}$ & $\begin{array}{l}\text { Program yang ditawarkan mengajarkan masyarakat } \\
\text { untuk melakukan penanaman hidroponik dengan } \\
\text { tujuan meningkatkan produtivitas masyarakat. }\end{array}$ \\
\hline Context & $\begin{array}{l}\text { Kemampuan melihat } \\
\text { hubungan antara rancangan } \\
\text { dengan lingkungan. }\end{array}$ & $\begin{array}{l}\text { Mempertahankan kontur dan lahan hijau existing } \\
\text { tapak. }\end{array}$ \\
&
\end{tabular}




\section{Konsep Tapak}

Dari hasil analisis tapak dan lingkungan, fungsi zonasi, sirkulasi dan kebisingan, sebagai titik dasar pengaturan zonasi aktivitas dalam tapak. Diarahkan aktivitas umum lebih berorientasi ke jalan lokal dengan tujuan agar pencapaiannya lebih mudah bagi pejalan kaki. Untuk ruangan yang mencangkup aktivitas publik seperti pasar, foodcourt atau auditorium lebih berorientasi ke jalur besar dikarenakan pencapaian mayoritas menggunakan kendaraan. Tapak dibagi ke dalam 3 zona, yaitu zona workshop/komunitas, zona olahraga dan juga zona pengelola. Zona workshop terdiri dari ruang kelas workshop, ruang workshop tari dan lukis, workshop urban vertical farming, dan juga fasilitas seperti auditorium dan Co-Learning Space. Zona olahraga terdiri dari lapangan, ruang ganti dan ruang loker. Zona pengelola sendiri terdiri dari ruang kantor pengelola, pantry, ruang rapat, dan sebagainya. Penerapan zoning pada ruang-ruang dalam bangunan sebagai berikut:

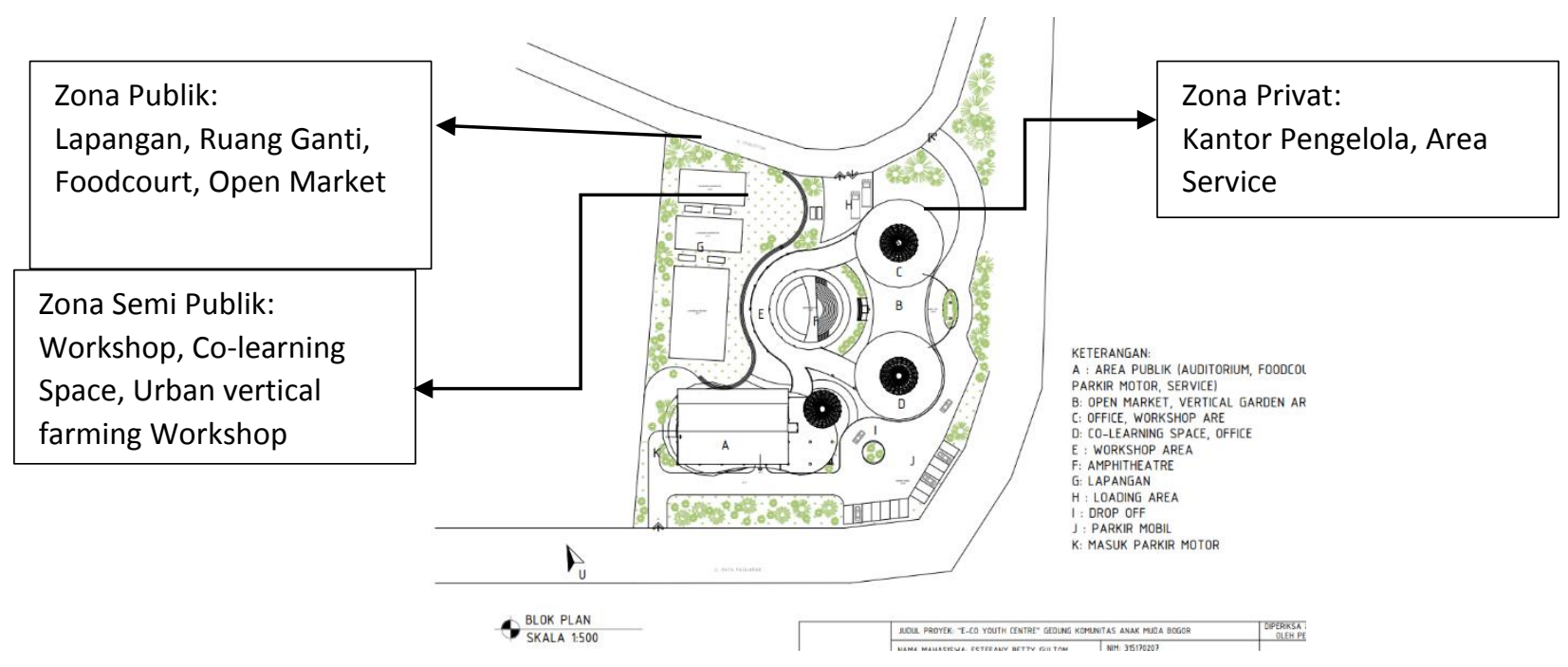

Gambar 8. Zonasi Dalam Bangunan

Sumber: Data Penulis

Konsep gubahan massa di proyek ini adalah menggunakan pola tepusat, dikarenakan menyesuaikan dengan fungsi bangunan sesuai program yaitu bagian tengah tapak difungsikan untuk tempat berkumpul (amphitheatre). Untuk konsep dari bentuk masa yang melingkar berasal dari upaya merespon amphitheatre dan sistem teknologi pengairan di bangunan.
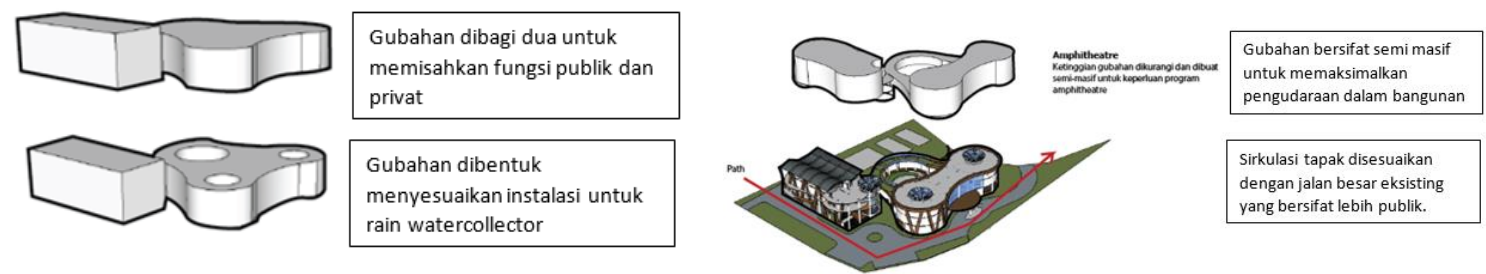

Gambar 9. Gubahan massa

Sumber: Data Penulis, 2021

Area foodcourt berada di lantai dua dan berhubungan langsung dengan rooftop garden. Mayoritas massa bangunan bersifat semi masif guna untuk menyesesuaikan dengan keadaan saat ini dimana membutuhkan aliran udara semaksimal mungkin untuk mencegah penyebaran virus. 


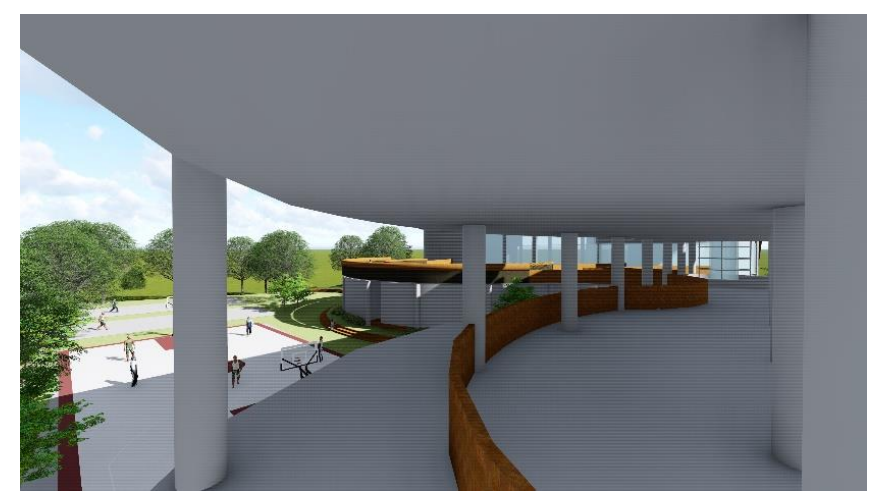

Gambar 10. Perspektif Foodcourt Sumber: Data Penulis

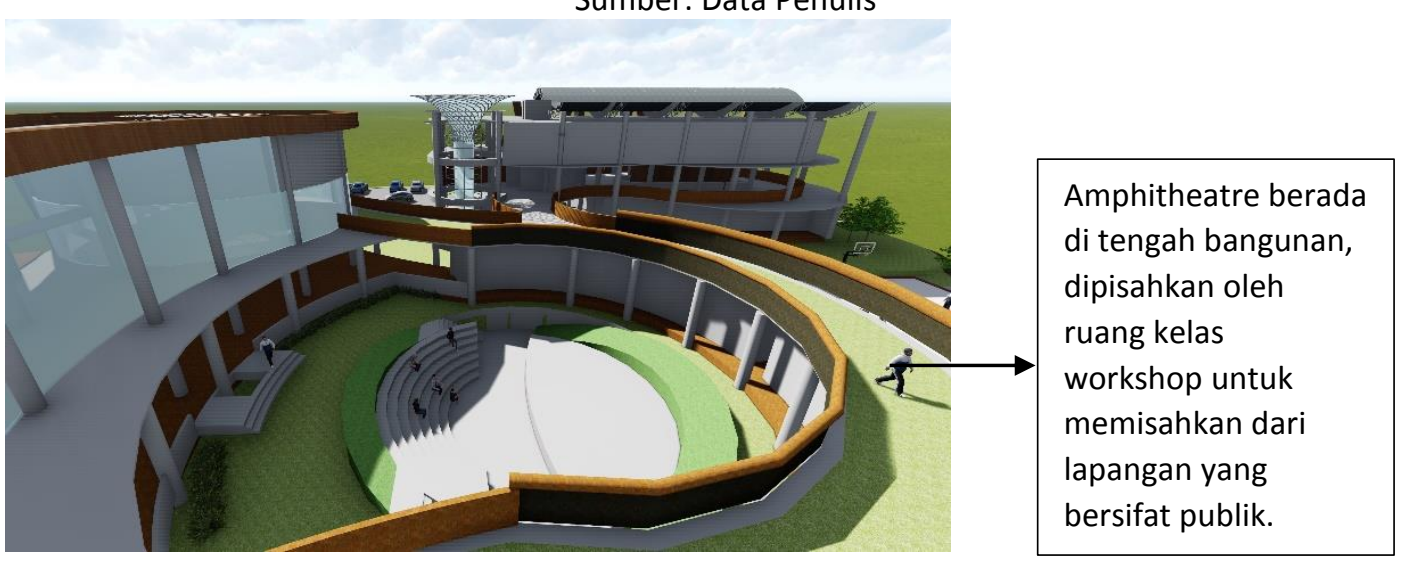

Gambar 11. Perspektif Rooftop Garden Sumber: Data Penulis

\section{Zonasi}

Terdapat dua massa pada tapak, untuk memisahkan zona area publik, semi publik dan private. Zona publik yang terdiri dari lapangan, foodcourt dan taman; berorientasi ke jalan lokal yang berada di belakang tapak. Orientasi ke jalan lokal diutamakan agar lebih mudah diakses melalui kendaraan umum atau pedestrian. Untuk zonasi yang bersifat publik terdiri dari program open market, co-learning space dan foodcourt, berorientasi ke arah jalan utama. Dengan tujuan aar mudah diakses oleh kendaraan pribadi.

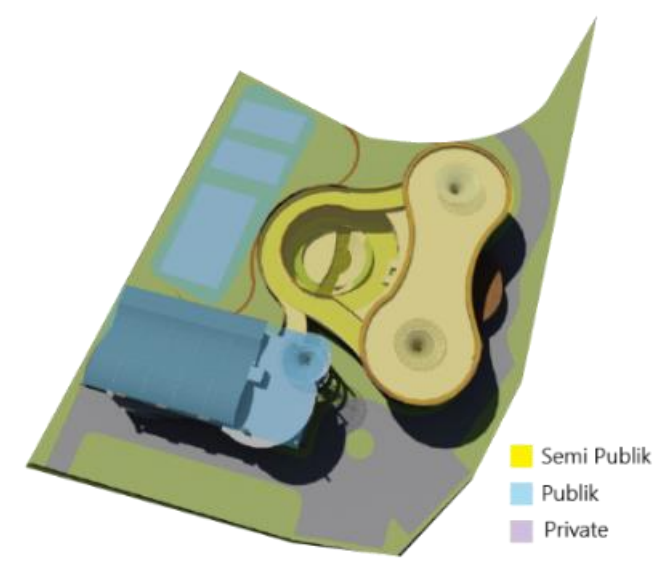

Gambar 12. Perspektif Tampak Atas

Sumber: Data Penulis, 2021 
Lantai dasar bersifat publik yang dimana diisi oleh open market, lapangan dan area parkir. Lantai dua bersifat semi publik yang diisi oleh workshop urbn vertical garden. Lantai tiga bersifat privat yang berisi kantor pengelola, ruang meeting dan sebagainya. Pencapaian menuju tiap lantai menggunakan lift dan ada tangga darurat.

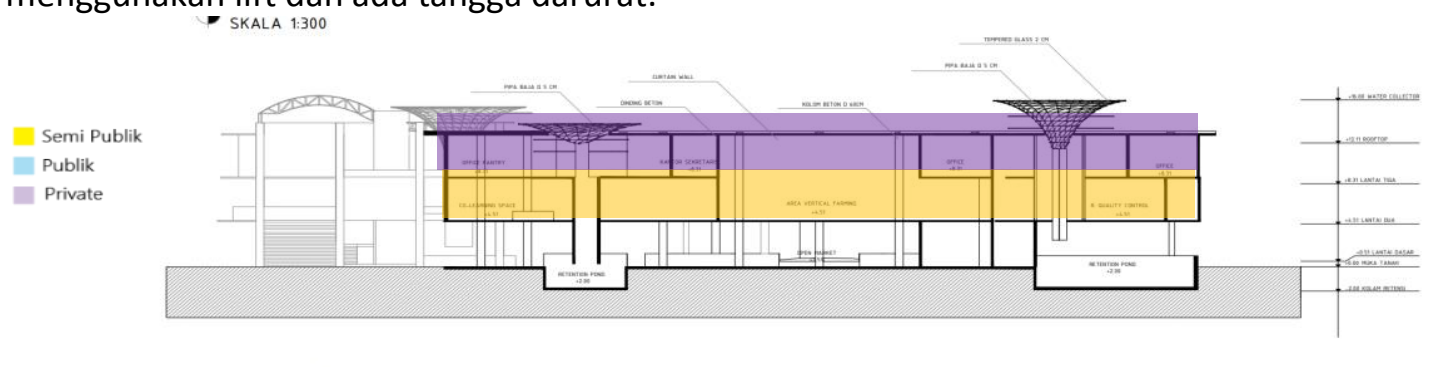

a POTONGAN B-B

Gambar 13. Potongan Bangunan

Sumber: Data Penulis, 2021

\section{Sirkulasi}

Pencapaian menuju bangunan dapat melewati dua jalan besar untuk pengguna yang membawa kendaraan pribadi, dan bisa juga melalui jalan lokal yang berada di belakang tapak. Jalan lokal di orientasikan untuk pengunjung yang menggunakan kendaraan umum atau pencapaian dengan jalan kaki.

Alur sirkulasi di dalam bangunan mulai dari entrance yang terbagi menjadi dua, ada entrance untuk kendaraan dan pejalan kaki. Untuk pengunjung yang membawa kendaraan pribadi, masuk melalui entrance yang berada di Jl. Raya Bogor-Sukabumi, kemudian menuju drop off pertama yang berorientasi ke fungsi foodcourt dan ruang kelas workshop. Di depan drop off terdapat parkir mobil. Lalu menuju ke drop off dua yang berorientasi ke open market pada bangunan, dan kemudian menuju pintu keluar di Jl. Cikabuyutan.

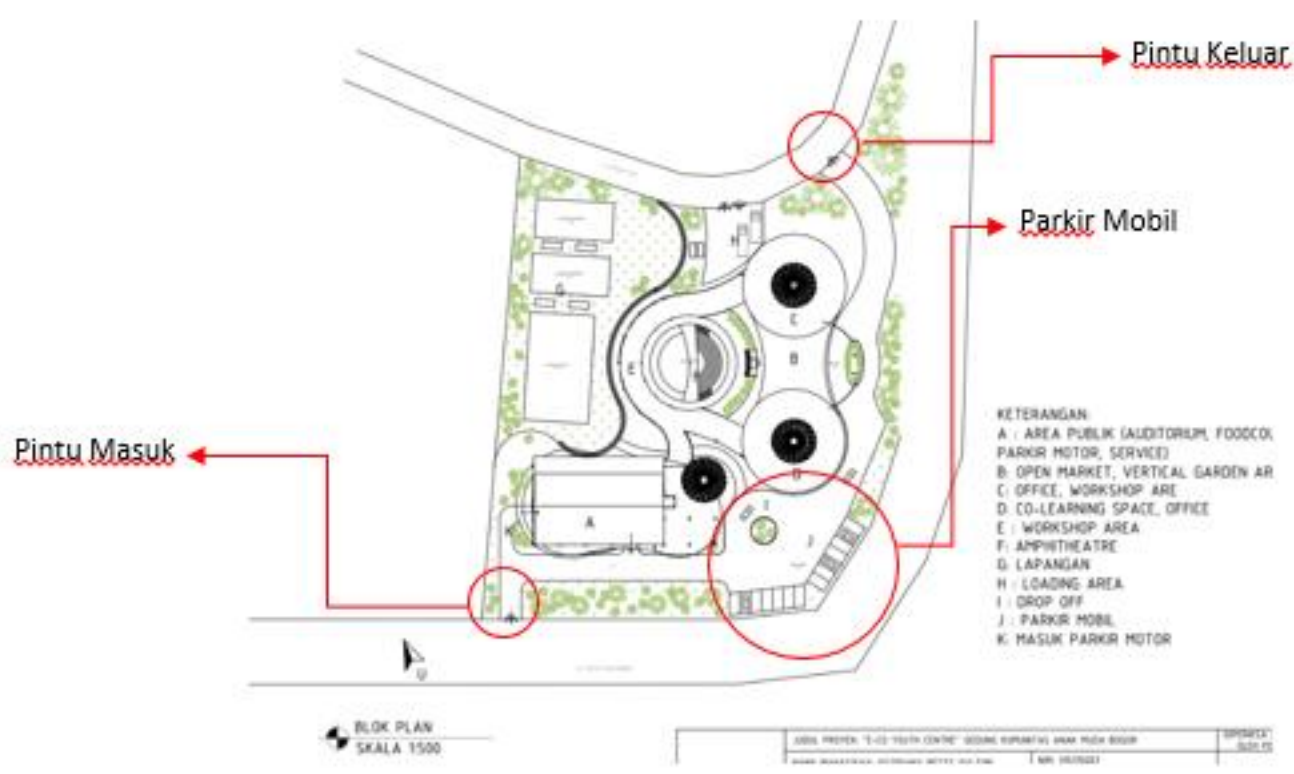

Gambar 14. Gambar Blok Plan

Sumber: Data Penulis, 2021 


\section{Struktur dan Material}

Material yang digunakan dalam perancangan ini , menggunakan struktur beton dan penggunaan ornamen-ornamen yang berfungsi sebagai pembatas atau filter antara bangunan yang bersifat semi masif, dengan linkungan luar. Bentuk atap bangunan sendiri berupa dak beton disatu massa, karena fungsinya yang sebagai rooftop garden. Untuk massa lainnya atap menggunakan struktur baja.

Bangunan banyak menggunakan halfwall pada dindingnya yang bertujuan untuk memaksimalkan sirkulasi udara dan cahaya alami dari matahari. Penggunaan halfwall juga berfungsi untuk menghemat energi sistem pengudaraan bangunan.

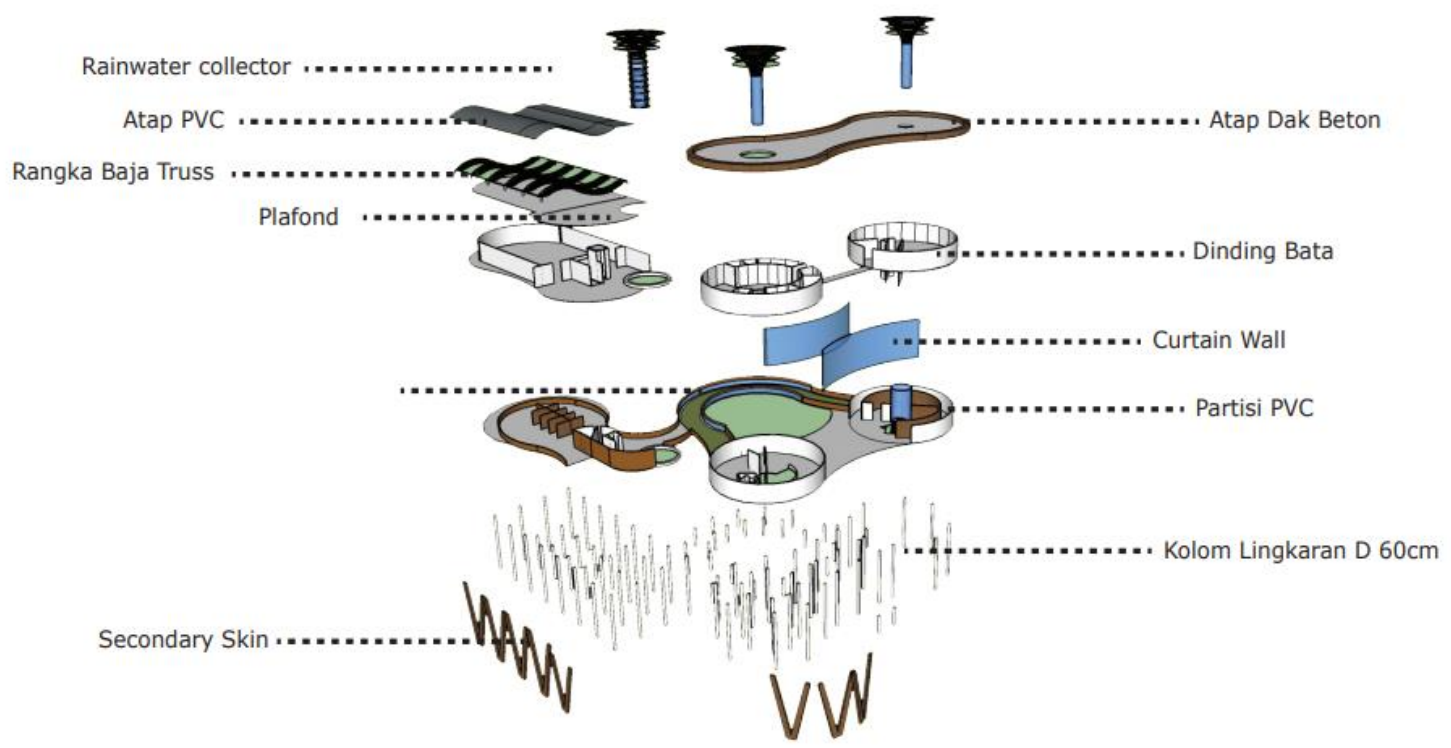

Gambar 15. Aksonometri Struktur Bangunan

Sumber: Data Penulis, 2021

\section{Rainwater Collector}

Sistem rainwater collector menggunakan material pipa baja untuk mengumpulkan air hujan lalu air hujan akan ditampung di kolam retensi dan di filtrasi agar dapat digunakan di bangunan kembali. Air di distribusikan menggunakan pompa keseluruh bangunan. Air yang sudah difiltrasi diutamakan untuk penggunaan di vertical garden. 


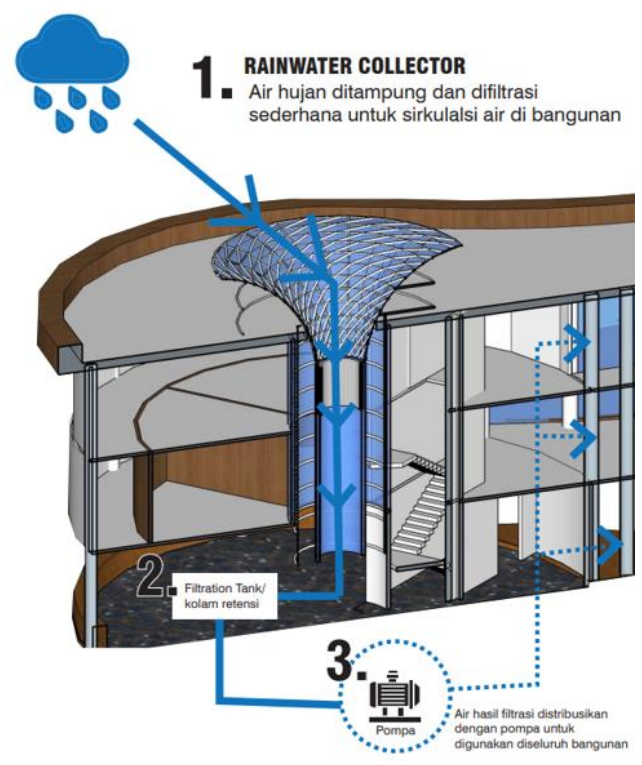

Gambar 16. Sistem Rainwater Collector Sumber: Data Penulis

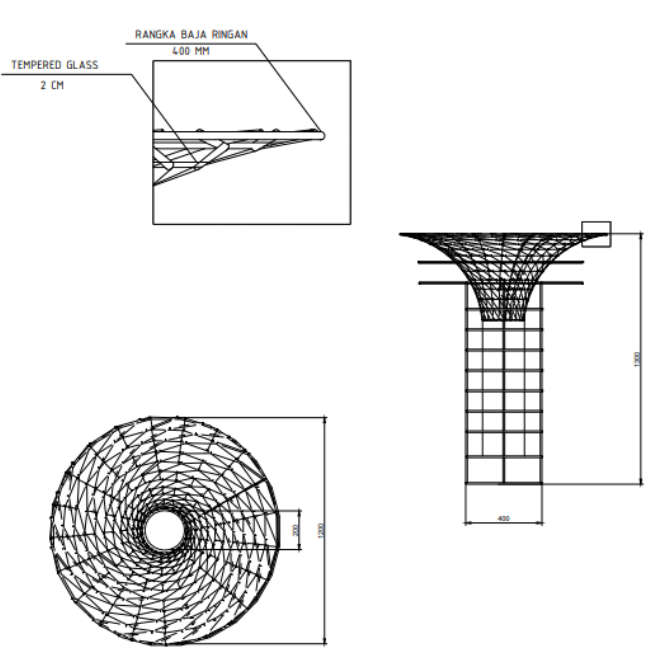

Gambar 17. Detail Rainwater Collector Sumber: Data Penulis

\section{KESIMPULAN}

Perancangan Gedung Komunitas Anak Muda di Bogor merupakan objek bangunan komunitas masyarakat yang mewadahi kegiatan komunitas anak muda, mulai dari kegiatan olahraga hingga pembelajaran. Desain bangunan sendiri difokuskan ke penerapan arsitektur ekologis dalam bangunan dengan cara mengacu ke 6 Beyond Ecology Principal. Penggunaan konsep tersebut bertujuan untuk menciptakan bangunan yang ramah lingkungan, mulai dari penggunaan energi, material hingga program yang dihasilkan. Pengaplikasian teknologi baru juga diterapkan pada program dan sistem pada bangunan. Program urban vertical garden diharapkan dapat mendukung kegiatan menanam dirumah bagi masyarakat kota Bogor yang mana akan bermanfaat karena adanya pembatasan kegiatan untuk keluar rumah, dengan program ini diharapkan pengguna dapat memulai menggunakan media baru dari rumah. Sistem Rainwater collector pada bangunan digunakan bertujuan untuk menghemat penggunaan energi, dengan cara menampung air hujan lalu memfiltrasi dan menggunakannya kembali sebagai sistem operasional bangunan. Program yang ditawarkan untuk anak muda bersifat non-akademik, diharapkan dapat menciptakan komunitas yang positif, dan juga mendukung kualitas anak muda di Kota Bogor.

\section{REFERENCES}

Day, C. (2003). Condensus Design Socially Inclusive Process. London: Architectural Press.

Frick, H., \& Suskiyatno, B. (1998). Dasar-Dasar Eko-Arsitektur. Yogyakarta: Kanisius. heinz. (n.d.). Kurokawa, K. (1994). Intercultural Architecture: The Philosophy of Symbiosis. Michigan: London: Academy Editions.

Parsons, T. (1951). The Social System. California: Glencoe III: Free Press.

Santrock, J. (2011). Perkembangan Anak Edisi 7. Jakarta: Erlangga.

Valenta, E. (2019, 11 20). Infografik : Anak-anak yang putus sekolah. Retrieved from lokadata: https://lokadata.id/artikel/infografik-anak-anak-yang-putus-sekolah 